\title{
APLIKASI KONSORSIUM MIKROBA UNTUK MEREMEDIASI TANAH TERKONTAMINASI TIMBAL DARI LIMBAH PROSES DEINKING INDUSTRI KERTAS
}

\author{
Krisna Septiningrum a *, Henggar Hardiani ${ }^{a}$ \\ ${ }^{a}$ Balai Besar Pulp dan Kertas, Bandung \\ Jl. Raya Dayeuhkolot No. 132 Bandung 40258 \\ Telp 022-5202980, Fax. 022-5202871 \\ * e-mail: krisnabio@yahoo.co.id
}

Diterima : 02 Maret 2011, Revisi Akhir : 21 November 2011

\section{ABSTRACT}

\section{APPLICATION OF MICROBE CONSORTIUM FOR REMEDIATION OF LEAD CONTAMINATED SOIL FROM DEINKING PROCESS IN PAPER INDUSTRY}

\begin{abstract}
Lead contaminated soil bioremediation using microbial consortium has been conducted on laboratorioum scale. Four types of lead accumulating bacteria, PG 65-06 (A): PG 97-02 (B): MR 1.12-05 (C) and A1 (D) with a ratio of 1:1:1:1 is used as microbial consortium. The study was conducted in 60 days with microbial inoculum variation of $5 \%, 10 \%, 15 \%(\mathrm{v} / \mathrm{w})$ and the addition of $5 \%$ microbial inoculum with rice straw as bulking agents. Observations were conducted every 10 days which concentration of $\mathrm{Pb}$, microbial activity, physico-chemical properties of soil before and after bioremediation as parameters. The addition of microbial consortium was proficient to remediate lead contaminated soil with a higher rate than the addition of $5 \%$ microbial inoculum with rice straw, which characterized by decreasing concentrations of soluble-exchangeable lead into residuals lead. The optimal condition occured in 40 days of incubation for addition of microbial inoculum $10 \%(\mathrm{v} / \mathrm{w})$, and 50 days incubations for addition of 5\% microbial inoculum with rice straw. The additions of rice straw enhanced indigenous microbial activity indicated by increasing quantity of soil microbes and $\mathrm{CO}_{2}$ production compared to addition of microbial inoculum. Characteristics of contaminated soil that has been remediated by microbes' consortium improved because the content of the soil macronutrients and micronutrients in remediated soil was better than previous.
\end{abstract}

Key words : bioremediation, lead, microbes consortium, deinking

\begin{abstract}
ABSTRAK
Bioremediasi tanah yang terkontaminasi timbal $(\mathrm{Pb})$ menggunakan konsorsium mikroba telah dilakukan pada skala laboratorium. Empat jenis bakteri pengakumulasi Pb, PG 65-06 (A): PG 97-02 (B): MR 1.12-05 (C) dan A1 (D) dengan perbandingan 1:1:1:1 digunakan sebagai konsorsium mikroba. Penelitian dilakukan selama 60 hari dengan variasi penambahan inokulum mikroba 5\%,10\%, 15\% (v/w) dan penambahan inokulum 5\%+ jerami padi sebagai bulking agents. Pengamatan dilakukan setiap 10 hari sekali dengan parameter konsentrasi logam $\mathrm{Pb}$, aktivitas mikroba tanah, serta analisis sifat fisika-kimia tanah pada awal dan akhir proses bioremediasi. Penambahan konsorsium mikroba dapat mempercepat proses remediasi logam $\mathrm{Pb}$ pada tanah terkontaminasi dibandingkan dengan konsorsium mikroba $5 \%+$ jerami, yang ditandai dengan menurunnya konsentrasi logam $\mathrm{Pb}$ dari fase tertukarkan menjadi fase residual. Perubahan fase tersebut optimal pada waktu inkubasi 40 hari pada penambahan inokulum $10 \%(\mathrm{v} / \mathrm{w})$ dan pada waktu inkubasi 50 hari pada penambahan mikroba 5\%+jerami. Penambahan jerami meningkatkan aktivitas mikroba indigenous yang ditunjukkan dengan meningkatnya jumlah mikroba tanah dan produksi $\mathrm{CO}_{2}$ yang dihasilkan dibandingkan penambahan inokulum mikroba. Karakteristik tanah terkontaminasi yang telah diremediasi oleh konsorsium mikroba menjadi lebih baik karena kandungan unsur hara tanah baik makro maupun mikro meningkat dibandingkan sebelum diremediasi.
\end{abstract}

Kata kunci : bioremediasi, $\mathrm{Pb}$, konsorsium mikroba, deinking 


\section{PENDAHULUAN}

Limbah sludge IPAL dari proses deinking mengandung logam berat yang berasal dari tinta yang larut dalam air limbah (Gottsching et al., 2000) sehingga diklasifikasikan sebagai limbah B3 dari sumber yang spesifik (Peraturan Pemerintah No. 18/1999 dan 85/1999 tentang Pengelolaan Bahan Berbahaya dan Beracun(B3)). PerMen-LH No. 33 Tahun 2009 menyatakan semua industri diwajibkan untuk melakukan pemulihan lahan terkontaminasi limbah B3 apabila membuang limbahnya secara timbunan terbuka. Salah satu logam berat dari proses deinking yang dapat mengkontaminasi tanah adalah timbal $(\mathrm{Pb})$. Hardiani (2008) menyatakan tanahterkontaminasilimbah tersebutmengandung $\mathrm{Pb}$ sejumlah $22 \mathrm{mg} / \mathrm{kg}$, kandungan $\mathrm{Pb}$ dalam tanah ini cukup tinggi jika dibandingkan dengan persyaratan logam $\mathrm{Pb}$ dalam tanah yaitu $20 \mathrm{mg} / \mathrm{kg}$ (Alloway, 1995). Oleh karena itu perlu dilakukan pemulihan (remediasi) tanah terkontaminasi pada lokasi bekas timbunan tersebut agar lahan yang tercemar dapat digunakan kembali untuk berbagai kegiatan secara aman.

$\mathrm{Pb}$ merupakan logam yang tidak terlalu mobil pada tanah dan biasanya tertahan beberapa sentimeter di permukaan tanah (Wasay et al, 2002), namun $\mathrm{Pb}$ dapat bermigrasi secara vertikal pada jenis tanah dan $\mathrm{pH}$ tertentu sehingga berdampak pada sumber air tanah (Wasay et al., 2002). Kemampuan tanah dalam meng-adsorb $\mathrm{Pb}$ meningkat tergantung dari beberapa faktor yaitu derajat keasaman $(\mathrm{pH})$ tanah, Kapasitas Tukar Kation (KTK), kandungan organik tanah, potensial redoks dan kandungan fosfat dalam tanah. Adsorbsi $\mathrm{Pb}$ sangat tinggi pada tanah yang bertekstur liat. Logam ini dapat di-absorb dalam bentuk mangan oksida atau ferioksida sebelum dimobilisasi. Senyawa $\mathrm{Pb}$ bersifat larut dan tidak terlalu larut dalam air, selain itu kelarutan logam $\mathrm{Pb}$ juga dipengaruhi oleh $\mathrm{pH} . \mathrm{Pb}$ mudah larut pada $\mathrm{pH}$ rendah dan $\mathrm{pH}$ tinggi (Wasay et al, 2002).

Proses remediasi logam $\mathrm{Pb}$ saat ini dilakukan secara fisika-kimia dengan menggunakan metode enkapsulasi atau vitrivikasi yang membutuhkan biaya tinggi. Prinsip dasar dari remediasi logam $\mathrm{Pb}$ adalah membuat logam tersebut immobil sehingga kemampuan tertukarkan logam $\mathrm{Pb}$ menurun (Yoon, 2005). Bioremediasi merupakan salah satu metode yang menjanjikan dan lebih ekonomis untuk membersihkan tanah atau air yang telah terkontaminasi logam berat dibandingkan dengan metode lainnya (Chatterjee et al., 2008).

Proses bioremediasi ini dapat dilakukan dengan menggunakan konsorsium mikroba atau mikroflora seperti bakteri, jamur dan ragi. Mikroba tanah tersebut berpengaruh secara langsung terhadap mobilitas logam dalam tanah yaitu dengan cara meningkatkan atau menurunkan mobilitas logam dalam tanah. Beberapa mekanisme yang dapat digunakan adalah biosorpsi, bioakumulasi, detoksifikasi, produksi asam atau agen pengkhelat seperti siderofor, transformasi redoks, pembentukan peptida dan protein yang berikatan dengan logam, presipitasi organik dan anorganik, transpor aktif, dan intracellular compartmentalization (Gadd, 2010). Beberapa faktor yang berpengaruh terhadap proses bioremediasi tersebut adalah yaitu aktivitas mikroba, nutrisi ( $\mathrm{N}$ dan $\mathrm{P}$ ), $\mathrm{pH}$, sumber energi (donor elektron), tekstur tanah, suhu, senyawa organik, kelembaban air, inhibitor atau metabolit dan mineral tanah (Mamik, 2004; Chatterjee, et al., 2008).

Konsorsium mikroba adalah sekumpulan mikroba yang bekerja sama dalam suatu kelompok sehingga mempunyai kemampuan lebih untuk mendegradasi suatu senyawa organik. Mikroba dalam konsorsium mempunyai peluang yang besar untuk memperoleh energi dan bertahan hidup, karena dapat saling memanfaatkan koenzim atau ekosoenzim yang diekskresikan oleh mikroba lainnya, selain itu mikroba lainnya dapat menguraikan substrat yang telah didegradasi sebelumnya oleh suatu mikroba. Notodarmojo (2005) menuturkan beberapa keuntungan menggunakan konsorsium mikroba adalah (1) dapat melakukan degradasi secara berurutan, (2) konsorsium dapat menghasilkan enzim atau zat yang dibutuhkan, (3) dapat meningkatkan laju degradasi substrat secara keseluruhan, (4) dapat mempermudah oksidasi, karena dapat mencari jalur secara termodinamik paling mudah.

Beberapa mikroba seperti Pseudomonas marginalis, Bacillus megaterium, Plectonema boryanum, Saccharomyces cerevisiae, Bradyrhizobium joponicum, Desulfosporosinus orientis dan Pseudomonas stutzeri diketahui mampu meremediasi $\mathrm{Pb}$ pada tanah terkontaminasi (Margareth dan Mangkoedihardjo, 2010). Suhendrayatna (2001) menyatakan Chlorella vulgaris (alga); Ecklonia radiata (alga); Phellinus badius (fungi); Pinus radiata (fungi); Saccharomyces cerevisie dapat 
mereduksi logam $\mathrm{Pb}$ berturut-turut sebesar 83; $100 ; 50 ; 21$ dan 34\% dengan metode passive active. Faktor paling berperan dalam proses ini adalah protein dan polisakarida akan membentuk ikatan kovalen dengan gugus amino dan gugus karbonil. Mikroba lainnya yaitu Phanerochaeta chrysosporium diketahui dapat mereduksi $\mathrm{Pb}$ aktif pada tanah terkontaminasi dengan penambahan jerami sebagai bulking agents pada skala bioreaktor (Huang et al. 2005). Mikroba tersebut menstabilkan logam $\mathrm{Pb}$ dengan cara mengubah logam $\mathrm{Pb}$ aktif menjadi inaktif setelah diremediasi selama 60 hari, sehingga $\mathrm{Pb}$ berada dalam fase tidak tersedia dalam tanah untuk tanaman, akibatnya jumlah $\mathrm{Pb}$ yang diakumulasi oleh tanaman dapat tereduksi. Penelitian lain yang dilakukan oleh Margareth dan Mangkoedihardjo (2010) menunjukkan kompos yang ditambahkan Bacillus substilis dengan perbandingan 1:1 dapat mereduksi $\mathrm{Pb}$ pada tanah dengan konsentrasi $25 \mathrm{mg} / \mathrm{kg}$ dalam waktu 2-3 minggu.

Erny et al. (2003) menyatakan empat jenis mikroba dari genus Bacillus yaitu PG 65-06, PG 97-02, MR 1.12-05 dan A1 diketahui mampu mengakumulasi logam $\mathrm{Pb}$ dalam tubuhnya. Keempat mikroba ini tumbuh subur pada media yang mengandung $\mathrm{Pb}$ dengan konsentrasi 662,4 ppm. Untuk mengetahui kemampuan mikroba tersebut dalam meremediasi tanah terkontaminasi limbah deinking, maka perlu dilakukan penelitian mengenai bioremediasi tanah terkontaminasi $\mathrm{Pb}$ dengan menggunakan konsorsium mikroba yang terdiri dari empat jenis mikroba tersebut. Penelitian ini diharapkan dapat dijadikan sebagai alternatif pengembangan teknologi pengolahan limbah ramah lingkungan dan dapat digunakan sebagai metode pemulihan tanah terkontaminasi logam berat $\mathrm{Pb}$. Kemampuan mikroba tersebut dapat dijadikan sebagai informasi bagi industri pulp dan kertas untuk memecahkan permasalahan pemulihan pembuangan sludge yang mengandung logam berat.

\section{BAHAN DAN METODE}

\section{Alat dan Bahan}

Bahan yang digunakan pada penelitian ini adalah tanah terkontaminasi yang berasal dari lahan pembuangan sludge yang telah tertimbun selama 3-5 tahun. Tanah timbunan ini diambil dari pabrik kertas proses deinking pada Kecamatan Gresik-Jawa Timur. Contoh tanah diambil secara acak dengan cara memetak $2 \times 2$ m pada kedalaman sekitar $1 \mathrm{~m}$. Contoh tanah tersebut kemudian dicampurkan, dikeringkan secara alami, diserbuk lalu disaring menggunakan saringan nylon dengan mesh $2 \mathrm{~mm}$. Tanah tersebut lalu diinkubasi selama 1 minggu agar tanah yang digunakan relatif homogen (Mamik, 2004). Mikroba yang digunakan dalam penelitian adalah campuran dari beberapa jenis bakteri pengakumulasi logam $\mathrm{Pb}$ yaitu PG 65-06 (A) : PG 97-02 (B); MR 1.1205 (C) dan A1 (D) dengan perbandingan 1:1:1:1. Kultur tersebut diperoleh dari Balai Besar Litbang Bioteknologi dan Sumberdaya Genetika Pertanian, Bogor. Medium yang digunakan untuk menumbuhkan mikroba adalah pepton glukosa ekstrak (PGE) cair. Komposisi medium PGE per L adalah pepton $4 \mathrm{~g}$; glukosa $2 \mathrm{~g}$; ekstrak ragi 1 $\mathrm{g}$; dan bakto agar $15 \mathrm{~g}$ (sebagai pemadat). $\mathrm{pH}$ medium diatur menjadi 7 dengan menggunakan $\mathrm{NaOH} 5 \mathrm{M}$. Selain itu juga digunakan jerami padi sebagai bulking agents.

Peralatan utama yang digunakan dalam penelitian ini adalah reaktor bioremediasi, yang terdiri dari rangkaian reaktor skala laboratorium dengan ukuran tinggi $30 \mathrm{~cm} \times$ diameter $10 \mathrm{~cm}$, $\mathrm{CO}_{2}$ removal trap, dan plastik penangkap $\mathrm{CO}_{2}$ (Gambar 1). Selain itu juga digunakan Horiba Gas Analyzer untuk pengukur gas $\mathrm{CO}_{2}$, autoclave, laminar air flow, shaker, sentrifuse, peralatan gelas untuk menyiapkan inokulum mikroba dan menguji parameter-parameter yang diukur pada penelitian ini, serta AAS untuk mengukur kadar $\mathrm{Pb}$ pada tanah terkontaminasi dan tanah yang telah diremediasi.

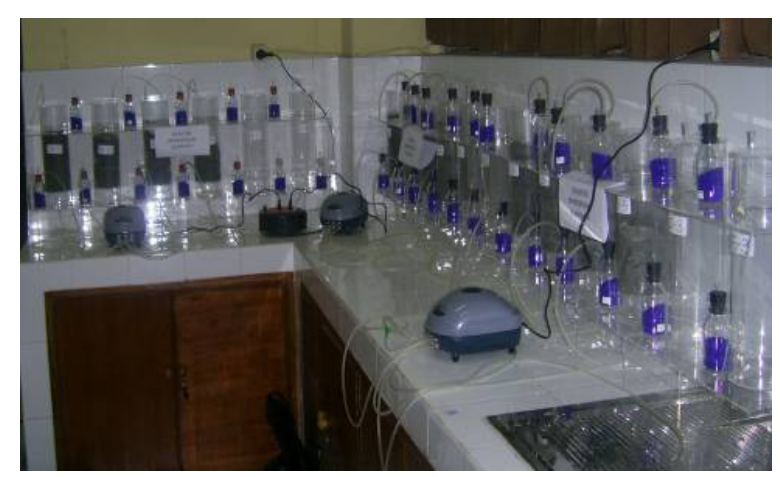

Gambar 1. Rangkaian Reaktor Skala Laboratorium untuk Percobaan Bioremediasi 


\section{Metode}

Penelitian dilakukan secara ex-situ pada skala laboratorium, tahapan percobaan dapat dilihat pada Gambar 2. Tahapan percobaan tersebut meliputi karakterisasi tanah terkontaminasi limbah proses deinking, pembuatan inokulum mikroba, percobaan bioremediasi dan pengujian.

1. Karakterisasi tanah terkontaminasi limbah proses deinking meliputi analisis logam $\mathrm{Pb}$ pada tanah terkontaminasi dan analisis sifat fisika-kimia tanah. Parameter logam yang diuji adalah $\mathrm{Pb}$. Metoda analisa mengacu pada Standard Methods for The Examination of Water and Wastewater, APHA, $21^{\text {st }}$ Edition, 2005 diukur dengan menggunakan Direct Air Acetylene Flame Methods, AAS. Sedangkan analisis fisika-kimia tanah meliputi tekstur, $\mathrm{pH}$, $\mathrm{C}, \mathrm{N}, \mathrm{C} / \mathrm{N}$ rasio, kandungan fosfat sebagai $\mathrm{P}_{2} \mathrm{O}_{5}$ (Olsen), K, KTK, Kejenuhan Basa (KB) dan unsur hara. Analisis dilakukan di Laboratorium Penguji, Badan Penelitian dan Pengembangan Pertanian Hortikultura, Lembang.

2. Pembuatan inokulum mikroba dilakukan sesuai dengan metode pada penelitian yang dilakukan oleh Hardiani (2011).
3. Percobaan bioremediasi. Desain eksperimen yang digunakan adalah dengan rancangan dasar acak faktorial dengan jumlah pengulangan 3 kali. Perlakuan pertama adalah penambahan jerami padi sebagai bulking agents, sedangkan perlakuan kedua adalah tanpa penambahan jerami. Perlakuan pertama terdiri dari dua faktor yaitu:

a. Faktor pertama adalah waktu inkubasi dengan 6 taraf yaitu 10, 20 30, 40, 50 dan 60 hari.

b. Faktor kedua adalah jumlah inokulum dengan 3 taraf yaitu kontrol (-) yaitu tanah terkontaminasi tanpa inokulum dan jerami, kontrol jerami dan inokulum $5 \%+$ jerami $(1: 6, \mathrm{v} / \mathrm{v})$

Perlakuan kedua terdiri dari dua faktor yaitu:

a. Faktor pertama adalah waktu inkubasi dengan 6 taraf yaitu 10, 20 30, 40, 50 dan 60 hari.

b. Faktor kedua adalah jumlah inokulum dengan 4 taraf yaitu kontrol (-), inokulum $5 \%, 10 \%$ dan $15 \%(\mathrm{v} / \mathrm{w})$

4. Parameter uji yang diamati selama percobaan berlangsung dan pada akhir percobaan yaitu:

Pembuatan inokulum mikroba PG 65-06 (A); PG 97-02 (B); MR 1.12-05 (C); A1 (D)

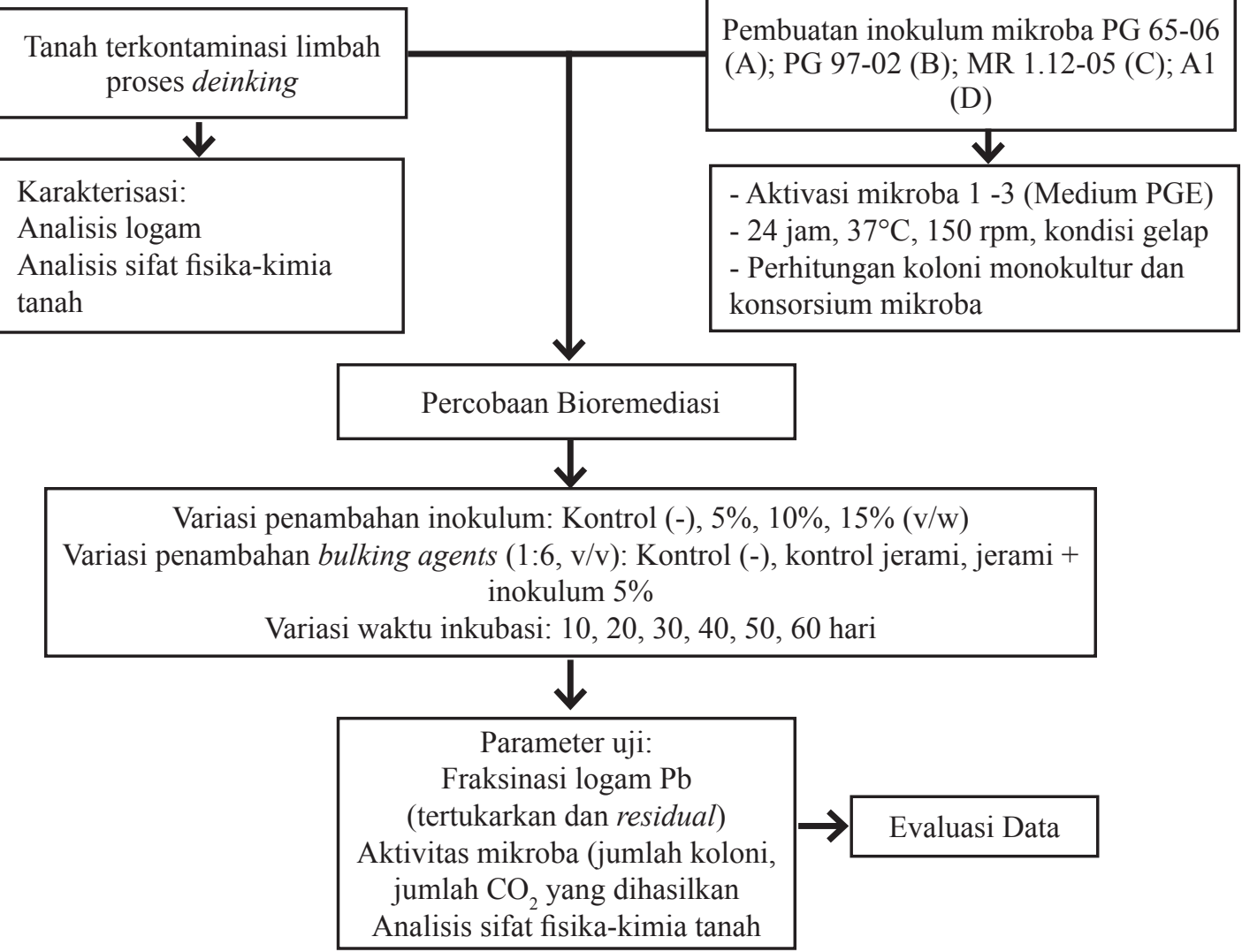

Gambar 2. Diagram Alir Penelitian Bioremediasi 
a. Fraksinasi logam $\mathrm{Pb}$ (tertukarkan dan residual) yang ditentukan menurut metode ekstraksi berurutan (Amanda, 2010)

b. Aktivitas mikroba. Parameter ini dilakukan dengan menghitung jumlah koloni mikroba dengan menggunakan metode TPC (Total Plate Count) dan pengenceran bertingkat, serta mengukur jumlah $\mathrm{CO}_{2}$ hasil metabolism mikroba yang dihasilkan pada plastik penangkap $\mathrm{CO}_{2}$. Jumlah $\mathrm{CO}_{2}$ yang dihasilkan diukur dengan menggunakan Horiba Gas Analyzer.

c. Analisis sifat fisika-kimia tanah meliputi tekstur, $\mathrm{pH}, \mathrm{C}, \mathrm{N}, \mathrm{C} / \mathrm{N}$ rasio, kandungan fosfat sebagai $\mathrm{P}_{2} \mathrm{O}_{5}$ (Olsen), $\mathrm{K}$, KTK, Kejenuhan Basa $(\mathrm{KB})$ dan unsur hara. Analisis dilakukan di Laboratorium Penguji, Badan Penelitian dan Pengembangan Pertanian Hortikultura, Lembang.

\section{HASIL DAN PEMBAHASAN}

\section{Karakteristik Tanah Terkontaminasi Limbah Proses Deinking}

Analisis tanah terkontaminasi limbah proses deinking sebelum proses bioremediasi dapat dilihat pada Tabel 1.

Tabel 1. Hasil Analisis Sifat Fisika Kimia Tanah Terkontaminasi

\begin{tabular}{|c|c|c|c|c|c|c|c|}
\hline \multirow[b]{2}{*}{ No } & \multirow[b]{2}{*}{ Parameter } & \multirow{2}{*}{$\begin{array}{c}\text { Tanah } \\
\text { Terkontaminasi }\end{array}$} & \multicolumn{5}{|c|}{$\begin{array}{c}\text { Kriteria Kualifikasi Tanah } \\
\text { (Pusat Penelitian Tanah, 1983) }\end{array}$} \\
\hline & & & $\begin{array}{l}\text { Sangat } \\
\text { Rendah }\end{array}$ & Rendah & Sedang & Tinggi & $\begin{array}{l}\text { Sangat } \\
\text { Tinggi }\end{array}$ \\
\hline 1 & $\begin{array}{l}\text { Tekstur } \\
\text { Pasir , \% } \\
\text { Debu , \% } \\
\text { Liat , \% }\end{array}$ & $\begin{array}{l}20 \\
21 \\
59\end{array}$ & - & - & - & - & - \\
\hline 2 & $\mathrm{pH}$ & 7,10 & $\begin{array}{l}4,5-5,5 \\
\text { masam }\end{array}$ & $\begin{array}{c}5,6-6,5 \\
\text { (agak } \\
\text { masam) }\end{array}$ & $\begin{array}{l}6,6-7,5 \\
\text { (netral) }\end{array}$ & $\begin{array}{c}7,6-8,5 \\
\text { (agak } \\
\text { alkalis) }\end{array}$ & $\begin{array}{l}>8,5 \\
\text { (alkali) }\end{array}$ \\
\hline \multirow[t]{3}{*}{3} & Nitrogen $(\mathrm{N}), \%$ & 0,15 & $<0,1$ & $0,1-0,2$ & $0,21-0,5$ & $0,51-0,75$ & $>0,75$ \\
\hline & Karbon (C), \% & 2,97 & $<1,00$ & $1,0-2,0$ & $2,01-3,0$ & $3,01-5,0$ & $>5,00$ \\
\hline & Rasio (C/N) & 19 & $<0,5$ & $5,0-10,0$ & $11-15$ & $16-25$ & $>25$ \\
\hline 4 & $\mathrm{P}_{2} \mathrm{O}_{5}$ Olsen, ppm & 38,70 & $<10$ & $10-25$ & $26-45$ & $45-60$ & $>60$ \\
\hline 5 & $\begin{array}{l}\text { Kalium }(\mathrm{K}), \mathrm{K}_{2} \mathrm{O} \\
\mathrm{mg} / 100 \mathrm{~g}\end{array}$ & 159,20 & 8 & 12 & 21 & 36 & 58 \\
\hline 6 & $\begin{array}{l}\text { Kapasitas Tukar } \\
\text { Kation (KTK), } \\
\text { me/100g }\end{array}$ & 37,55 & $<6$ & $6-12$ & $12-25$ & $25-40$ & $>40$ \\
\hline 7 & $\begin{array}{l}\text { Nilai Kejenuhan } \\
\text { Basa (KB), \% }\end{array}$ & 123 & $<20$ & $20-35$ & $36-50$ & $51-70$ & $>70$ \\
\hline \multirow[t]{5}{*}{8} & $\begin{array}{l}\text { Unsur hara } \\
(\mathrm{me} / 100 \mathrm{~g})\end{array}$ & & & & & & \\
\hline & $\mathrm{Ca}$ & 40,33 & $<2$ & $2-5$ & $6-10$ & $11-20$ & $>20$ \\
\hline & $\mathrm{Mg}$ & 5,37 & $<0,4$ & $0,4-1,0$ & $1,1-2,0$ & $2,1-8,0$ & $>8,0$ \\
\hline & $\mathrm{K}$ & 0,44 & $<0,1$ & $0,1-0,2$ & $0,3-0,5$ & $0,6-1,0$ & $>1,0$ \\
\hline & $\mathrm{Na}$ & 0,21 & $<0,1$ & $0,1-0,3$ & $0,4-0,7$ & $0,8-1,0$ & $>1,0$ \\
\hline
\end{tabular}

Sumber data : Laboratorium Penguji, Badan Penelitian dan Pengembangan Pertanian, Hortikultura, Lembang, 2010 
Hasil analisis tersebut dibandingkan dengan kisaran nilai untuk kualifikasi tanah menurut Pusat Penelitian Tanah (1983), menunjukkan bahwa analisis tekstur tanah terkontaminasi didominasi fraksi liat 59\% (>55\%), berarti tanah tersebut mempunyai tekstur liat. Tanah terkontaminasi mempunyai $\mathrm{pH}$ netral dengan nilai $\mathrm{pH} 7,1$, nilai $\mathrm{pH}$ akan mempengaruhi ketersediaan dan sifat meracun unsur logam terhadap mikroba. Tanah terkontaminasi memiliki KTK tanah tinggi yaitu sebesar 37,55 me/100g. Hasil analisis unsur hara menunjukkan bahwa tanah memiliki kandungan unsur hara esensial $\mathrm{K}, \mathrm{Ca}, \mathrm{P}$ dan $\mathrm{Mg}$ cukup tinggi, namun memiliki kandungan $\mathrm{N}$ yang rendah jika dibandingkan dengan standar kualifikasi tanah. Selanjutnya ditinjau dari nilai $\mathrm{C} / \mathrm{N}$ rasio, tanah memiliki nilai $\mathrm{C} / \mathrm{N}$ tinggi yaitu sebesar 19 . Kondisi ini menunjukkan bahwa bahan organik yang ada di tanah kemungkinan sudah termineralisasi karena kandungan karbon yang sudah rendah $(2,97 \%)$. Berdasarkan kandungan unsur hara tersebut, maka penambahan nutrisi pada percobaan bioremediasi tidak perlu dilakukan, karena tanah sudah cukup mengandung makronutrisi dan mikronutrisi yang diperlukan oleh mikroba untuk melakukan aktivitas hidupnya.

Hasil analisis logam berat dari tanah terkontaminasi menunjukkan tanah mengandung $\mathrm{Pb} 61,8 \%$ lebih tinggi daripada sludge yaitu sebesar $63,1 \mathrm{mg} / \mathrm{kg}$ (Hardiani, 2011). Meningkatnya kandungan logam pada tanah terkontaminasi menunjukkan bahwa logam telah terkonsentrasi dalam tanah karena sudah terkontaminasi cukup lama (3-5 tahun), akibatnya senyawa organik yang ada telah termineralisasi sehingga kandungan logam berat pada tanah meningkat. Kandungan $\mathrm{Pb}$ ini pada dasarnya sudah melebihi batasan level A yaitu $<50 \mathrm{~kg} / \mathrm{kg}$ (background level) yang ditetapkan oleh Menteri Lingkungan dan Kehutanan (MEFQ) di Quebec (MEFQ, 1994 dalam Wasay et al., 2002) namun masih dibawah level B (150 mg/ $\mathrm{kg})$ dan level C $(600 \mathrm{mg} / \mathrm{kg})$ yang membutuhkan penelitian dan proses cleaning sebelum dibuang di tanah. Meskipun masih berada pada level B dan C, logam $\mathrm{Pb}$ dikategorikan sebagai bahan berbahaya dan beracun (B3) sehingga keberadaan logam berat tersebut dalam tanah perlu mendapatkan perhatian yang serius karena 1 . bersifat racun bagi pertumbuhan, metabolisme tanaman (Shah dan Nongkynrih, 2007) dan berpotensi karsinogenik; 2. bersifat mobil pada tanah liat pada $\mathrm{pH}$ tertentu (Wasay et al., 2002); 3. mempunyai sifat akumulatif dalam tubuh manusia (Notodarmojo, 2005).

\section{Aktivitas Mikroba Tanah}

Untuk mengetahui aktivitas mikroba tanah selama percobaan berlangsung maka dilakukan perhitungan jumlah mikroba tanah dan jumlah $\mathrm{CO}_{2}$ yang dihasilkan. Jumlah mikroba tanah selama percobaan untuk perlakuan tanpa penambahan jerami dan penambahan jerami dapat dilihat pada Gambar 3A dan 3B.

\section{A. Jumlah Mikroba Tanah}

Salah satu faktor keberhasilan bioremediasi logam berat adalah aktivitas mikroba tanah. Berdasarkan hal tersebut maka perlu dilakukan variasi penambahan jumlah inokulum untuk mendapatkan jumlah inokulum optimal dalam proses remediasi logam $\mathrm{Pb}$.
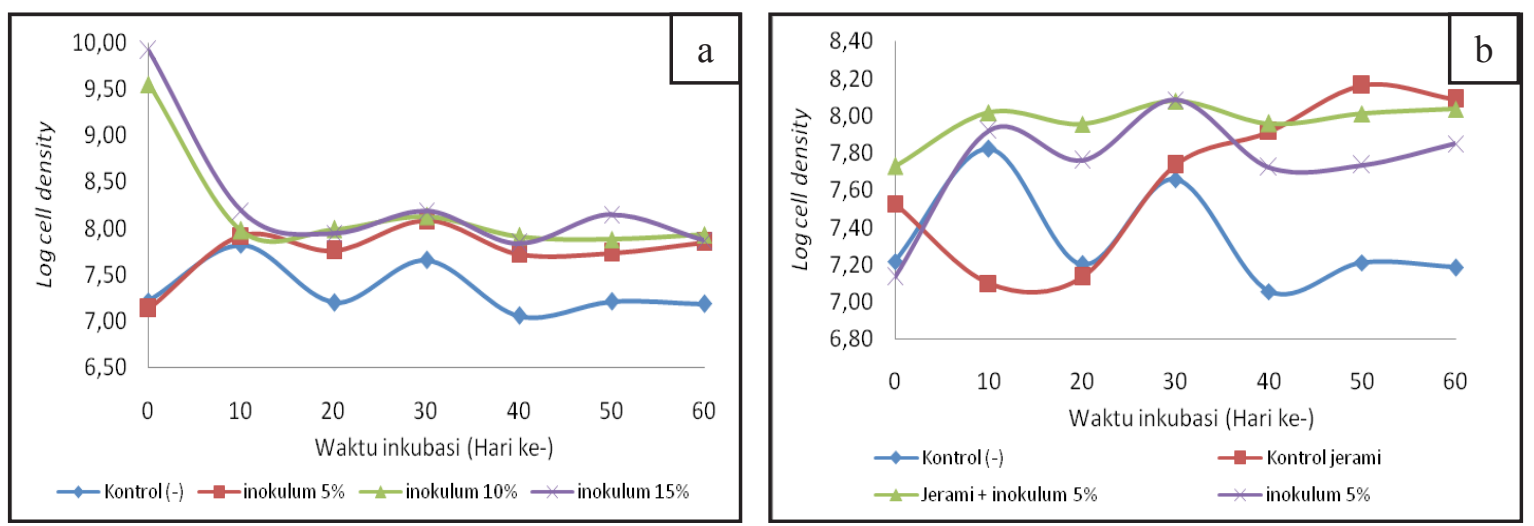

Gambar 3. Jumlah Mikroba dalam Reaktor Bioremediasi

a. Perlakuan tanpa Penambahan Jerami

b. Perlakuan dengan Penambahan Jerami 
Jumlah inokulum awal konsorsium mikroba yang digunakan dalam penelitian ini adalah $10^{9} \mathrm{CFU} / \mathrm{ml}$ (log cell density 9,1). Inokulum tersebut merupakan hasil konsorsium 4 jenis bakteri yaitu PG 65-06 (A), PG 97-02 (B), MP 1.12-05 (C) dan A1 (D) dengan perbandingan 1:1:1:1 (v/v). Keempat bakteri tersebut digunakan dalam penelitian ini karena diketahui mampu mengakumulasi logam $\mathrm{Pb}$ dalam selnya (Erny et al., 2003). Selama percobaan tidak dilakukan variasi perbandingan bakteri yang digunakan karena hanya ingin mengetahui kemampuan keempat jenis bakteri dalam meremediasi logam $\mathrm{Pb}$. Mikroba yang digunakan pada percobaan ini berupa bakteri karena dapat berkembang biak dengan baik di lingkungan terkontaminasi dan lebih mampu bertahan hidup pada lingkungan dengan keterbatasan $\mathrm{C}, \mathrm{N}$ dan substrat karena memiliki aktivitas metabolik yang lebih baik dibandingkan mikroba lainnya (Mamik, 2004).

Untuk perlakuan tanpa penambahan jerami, secara umum hasil percobaan menunjukkan jumlah mikroba tanah untuk penambahan inokulum 5\%, $10 \%$ dan $15 \%$ lebih tinggi jika dibandingkan dengan kontrol (-). Jumlah mikroba tanah pada perlakuan kontrol negatif meningkat tajam pada hari ke-10 dan 30 kemudian menurun sampai dengan hari ke-60. Jumlah mikroba tanah pada perlakuan inokulum 5\% cenderung meningkat tajam sampai dengan hari ke-30 kemudian cenderung stabil sampai dengan hari ke-60. Sedangkan untuk perlakuan penambahan inokulum $10 \%$ dan $15 \%$, jumlah mikroba tanah menurun tajam pada hari ke10 kemudian cenderung stabil sampai dengan akhir pengamatan. Penurunan jumlah mikroba tanah pada penambahan inokulum $10 \%$ dan $15 \%$ pada hari ke-10 jika dibandingkan dengan kontrol negatif disebabkan karena mikroba yang ditambahkan ke dalam reaktor (extraneous microbes) masih dalam masa adaptasi dan belum mampu berkompetisi dengan mikroba indigenous yang sudah ada pada tanah terkontaminasi. Selain itu karena kondisi lingkungan yang kurang mendukung pertumbuhan mikroba karena adanya penurunan kadar air di dalam reaktor akibat adanya evaporasi selama percobaan berlangsung.

Untuk perlakuan penambahan jerami, jumlah mikroba tanah untuk perlakuan kontrol jerami dan jerami+inokulum $5 \%$ cenderung lebih tinggi jika dibandingkan dengan kontrol negatif. Untuk perlakuan kontrol jerami, jumlah mikroba tanah menurun tajam sampai dengan hari ke-20, kemudian meningkat tajam sampai dengan hari ke60. Hal yang berbeda ditunjukkan pada perlakuan penambahan jerami+inokulum 5\%, jumlah mikroba tanah cenderung meningkat seiring dengan waktu inkubasi. Jumlah mikroba tanah untuk perlakuan penambahan jerami+inokulum 5\% lebih tinggi jika dibandingkan dengan penambahan inokulum 5\% namun cenderung sebanding dengan penambahan inokulum 10\% dan 15\%. Jumlah mikroba tanah pada perlakuan penambahan jerami meningkat karena jerami meningkatkan porositas tanah akibatnya aerasi tanah semakin baik, jika aerasi tanah meningkat maka ketersediaan oksigen di dalam tanah cenderung meningkat akibatnya mikroba dapat melakukan aktivitas hidupnya lebih baik sehingga mampu berproduksi untuk meningkatkan populasinya dalam tanah.

\section{B. Produksi Gas $\mathrm{CO}_{2}$}

Pengaruh perlakuan tanpa penambahan jerami dan penambahan jerami terhadap produksi $\mathrm{CO}_{2}$ dapat dilihat pada Gambar 4A dan 4B.

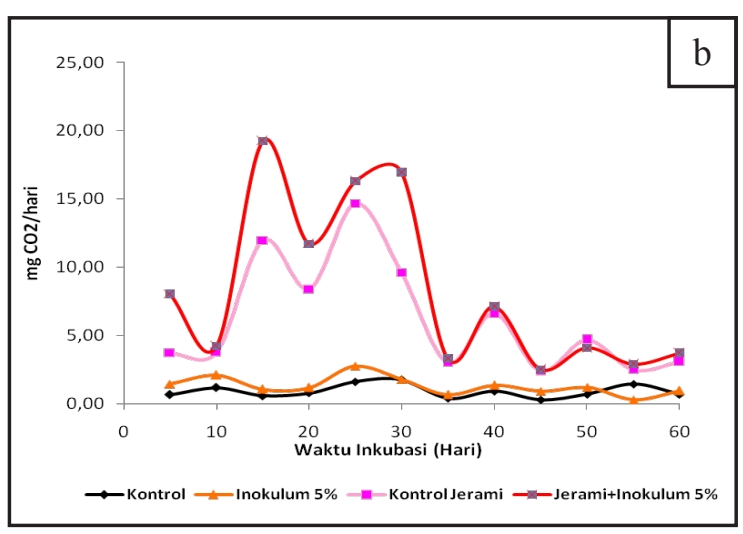

Gambar 4. Produksi $\mathrm{CO}_{2}$ dalam Reaktor Bioremediasi

a. Perlakuan tanpa Penambahan Jerami

b. Perlakuan dengan Penambahan Jerami 
Produksi $\mathrm{CO}_{2}$ dapat digunakan untuk mengetahui aktivitas mikroba karena gas $\mathrm{CO}_{2}$ merupakan produk akhir dari respirasi mikroba, semakin tinggi produksi $\mathrm{CO}_{2}$ menunjukkan aktivitas mikroba dalam bioreaktor semakin baik. Secara umum, penambahan inokulum dapat meningkatkan produksi $\mathrm{CO}_{2}$ jika dibandingkan dengan kontrol negatif kecuali pada hari ke-40 pada penambahan inokulum 15\% dan hari ke-55 untuk penambahan inokulum 5\% dan 15\%.

Untuk penambahan inokulum $5 \%$, produksi $\mathrm{CO}_{2}$ yang dihasilkan berfluktuasi namun cenderung lebih tinggi jika dibandingkan dengan kontrol negatif. Pada penambahan inokulum 10\%, produksi $\mathrm{CO}_{2}$ meningkat sampai dengan hari ke20 kemudian cenderung menurun sampai dengan hari ke-45 kemudian meningkat sampai dengan hari ke-60. Kecenderungan serupa terjadi pada perlakuan dengan inokulum $15 \%$, produksi $\mathrm{CO}_{2}$ awalnya cukup besar rata-rata $2,88 \mathrm{mg} \mathrm{CO} /$ hari (waktu inkubasi hari ke-5) meningkat menjadi 2,39 mg $\mathrm{CO}_{2}$ /hari (hari ke 30), selanjutnya menurun dan cenderung konstan sampai dengan hari ke 60 , yaitu sebesar $1,24 \mathrm{mg} \mathrm{CO}_{2}$ /hari. Pola produksi $\mathrm{CO}_{2}$ pada perlakuan tanpa penambahan jerami ini seiring dengan pola pertumbuhan mikroba selama percobaan berlangsung untuk seluruh penambahan inokulum yang digunakan pada percobaan.

Secara umum, jumlah $\mathrm{CO}_{2}$ yang diproduksi untuk perlakuan penambahan jerami cenderung lebih tinggi jika dibandingkan dengan perlakuan tanpa jerami (kontrol negatif dan inokulum 5\%) serta memiliki pola yang serupa baik untuk kontrol jerami maupun jerami+inokulum 5\%. Produksi $\mathrm{CO}_{2}$ pada kontrol jerami meningkat sejumlah 5 kali $\left(3,72 \mathrm{mg} \quad \mathrm{CO}_{2} /\right.$ hari $)$ jika dibandingkan dengan kontrol negatif $(0,66 \mathrm{mg}$
$\mathrm{CO}_{2}$ /hari) setelah diinkubasi selama 5 hari. $\mathrm{CO}_{2}$ yang diproduksi meningkat cukup tajam pada hari ke-15, menurun pada hari ke-20, mencapai maksimal pada hari ke-25, lalu menurun dan cenderung konstan sampai dengan akhir inkubasi. Kecenderungan yang serupa juga ditunjukkan pada perlakuan penambahan jerami+inokulum $5 \%, \mathrm{CO}_{2}$ yang diproduksi meningkat sekitar $550 \%$ pada hari ke-5 yaitu 1,44 $\mathrm{mg} \mathrm{CO}_{2}$ /hari menjadi $8,04 \mathrm{mg} \mathrm{CO}_{2}$ /hari. Produksi $\mathrm{CO}_{2}$ meningkat dari $8,04 \mathrm{mg} \mathrm{CO} /$ hari pada waktu inkubasi hari ke-5 menjadi 16,97 $\mathrm{mg} \mathrm{CO}$ /hari pada hari ke 30, selanjutnya menurun dan cenderung konstan sampai dengan hari ke-60 (3,72 $\mathrm{mg} \mathrm{CO}$ /hari). Pola produksi $\mathrm{CO}_{2}$ untuk perlakuan penambahan jerami ini seiring dengan pertumbuhan mikroba tanah selama percobaan berlangsung terutama untuk perlakuan konrol jerami. Secara umum dapat dikatakan penambahan jerami memberikan pengaruh positif terhadap aktivitas mikroba tanah pada reaktor yang ditandai dengan meningkatnya produksi $\mathrm{CO}_{2}$ yang dihasilkan.

\section{Pengaruh Konsorsium Mikroba (Perlakuan Tanpa Penambahan Jerami) dalam Remediasi Logam $\mathbf{P b}$}

Kunci keberhasilan bioremediasi $\mathrm{Pb}$ oleh aktivitas mikroba ditunjukkan dengan adanya perubahan fase logam dari aktif menjadi inaktif. Perubahan ini diketahui dari konsentrasi $\mathrm{Pb}$ pada fase tertukarkan ( $\mathrm{Pb}$ aktif) dan konsentrasi $\mathrm{Pb}$ pada fase residual (Pb tidak aktif) (Huang et al., 2005). Pengaruh jumlah inokulum $(5 \% ; 10 \%$ dan $15 \%)$ pada tanah terkontaminasi $\mathrm{Pb}$ tanpa penambahan jerami pada fase tertukarkan dan fase residual dapat dilihat pada Gambar 5A dan 5B.
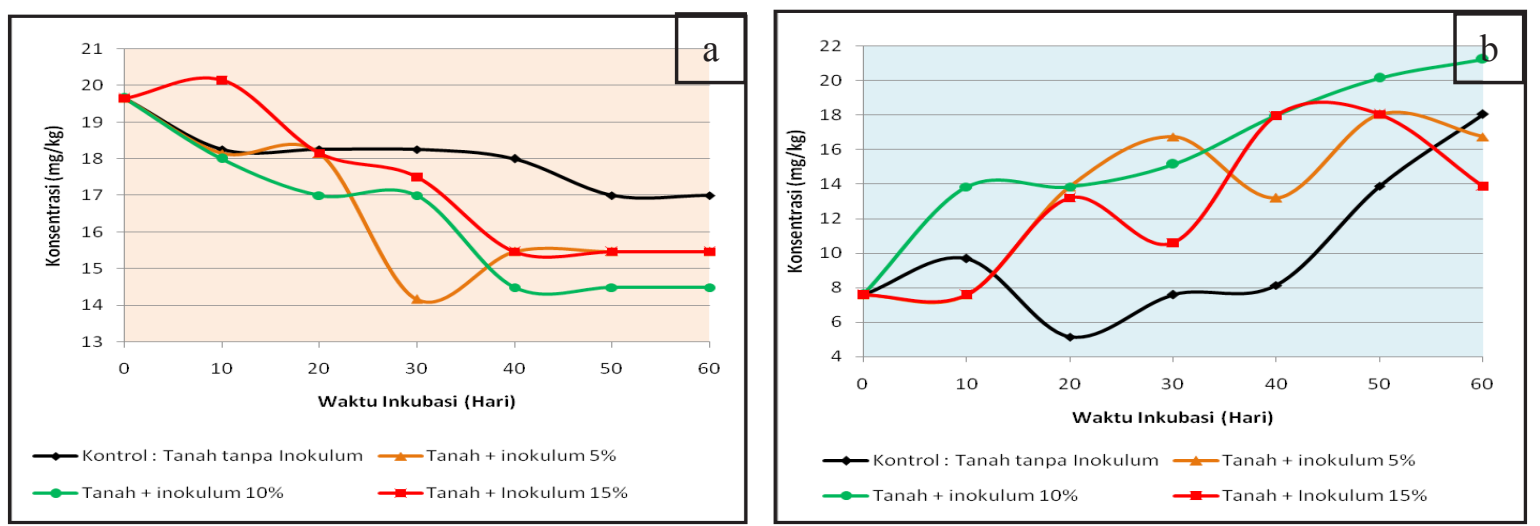

Gambar 5. Pengaruh Perlakuan Tanpa Jerami pada Konsentrasi Pb pada Beberapa Fase

a. Fase Tertukarkan

b. Fase Residual 
Secara umum diketahui bahwa penambahan inokulum mikroba dapat mengubah $\mathrm{Pb}$ dari fase aktif menjadi tidak aktif jika dibandingkan dengan kontrol negatif, hal ini diketahui dari meningkatnya konsentrasi $\mathrm{Pb}$ pada fase residual jika dibandingkan dengan konsentrasi pada fase tertukarkan. Hal ini sesuai dengan pernyataan Chatterjee, et al. (2008) bahwa kecepatan bioremediasi pada tanah terkontaminasi akan meningkat jika ditambahkan mikroba atau dengan menyediakan lingkungan yang sesuai untuk kehidupan mikroba. Pada kontrol negatif, proses remediasi logam $\mathrm{Pb}$ juga terjadi, namun dengan waktu inkubasi yang lebih lambat dan konsentrasi yang lebih rendah jika dibandingkan dengan penambahan inokulum. Hal ini menunjukkan mikroba indigenous tanah pada dasarnya dapat meremediasi logam $\mathrm{Pb}$ secara alamiah. Hal ini sesuai dengan pernyataan Chatterjee, et al. (2008) yaitu efektivitas remediasi kontaminan secara alamiah tergantung pada miroba indigenous tanah namun terjadi pada kecepatan yang rendah.

Pada penambahan inokulum 5\%, konsentrasi $\mathrm{Pb}$ pada fase tertukarkan mulai menurun pada hari ke-20 kemudian cenderung konstan sampai dengan hari ke-60. Sedangkan untuk logam $\mathrm{Pb}$ pada fase inaktif, konsentrasi $\mathrm{Pb}$ pada fase residual mulai meningkat pada hari ke-30 kemudian berfluktuatif namun cenderung meningkat seiring dengan lamanya waktu inkubasi yang digunakan. Adanya ketidakseiringan antara $\mathrm{Pb}$ pada fase aktif dan inaktif kemungkinan disebabkan $\mathrm{Pb}$ berada pada fase lainnya seperti terikat karbonat, terikat organik atau terikat Fe-Mn (Amanda, 2010).

Untuk penambahan inokulum 10\%, konsentrasi logam $\mathrm{Pb}$ pada fase tertukarkan menurun tajam sejak hari ke-10 kemudian cenderung konstan sampai akhir waktu inkubasi, hal ini seiring dengan meningkatnya konsentrasi logam $\mathrm{Pb}$ residual. Konsentrasi $\mathrm{Pb}$ pada fase residual cenderung lebih tinggi jika dibandingkan dengan kontrol negatif, penambahan inokulum $5 \%$ dan $15 \%$. Sedangkan untuk penambahan inokulum 15\%, konsentrasi logam $\mathrm{Pb}$ pada fase tertukarkan cenderung meningkat pada hari ke10 kemudian menurun tajam sampai dengan hari ke-30, lalu konstan sampai akhir waktu inkubasi, hal ini seiring dengan konsentrasi logam $\mathrm{Pb}$ pada fase residual.

Jika dihubungkan dengan kondisi lingkungan di dalam reaktor, peningkatan konsentrasi $\mathrm{Pb}$ pada fase residual untuk seluruh perlakuan dapat terjadi karena $\mathrm{pH}$ lingkungan yang cenderung menurun dan mendekati netral dari awal inkubasi sampai dengan hari ke-60 (data tidak ditampilkan). $\mathrm{pH}$ awal inkubasi adalah 7,96, kemudian mendekati netral di hari ke-40, kemudian cenderung stabil sampai dengan hari ke-60 (pH berada pada rentang 6,92-7,2). Hal ini sesuai dengan pernyataan Wasay et al. (2002) bahwa kelarutan logam $\mathrm{Pb}$ meningkat jika $\mathrm{pH}$ mendekati 8 dan pada $\mathrm{pH} 6-8 \mathrm{~Pb}$ berada dalam bentuk $\mathrm{Pb}$ organik dan tidak terlarut.

Hasil penelitian menunjukkan proses remediasi logam $\mathrm{Pb}$ secara optimal terjadi pada penambahan inokulum $10 \%$ dengan waktu inkubasi 40 hari. Hal ini ditunjukkan dengan meningkatnya konsentrasi logam $\mathrm{Pb}$ pada fase residual sampai dengan akhir waktu inkubasi yang seiring dengan menurunnya konsentrasi logam $\mathrm{Pb}$ pada fase tertukarkan. Hal serupa pada dasarnya juga terlihat pada penambahan inokulum $15 \%$, namun konsentrasi $\mathrm{Pb}$ pada fase residual cenderung menurun sampai dengan akhir waktu inkubasi jika dibandingkan dengan penambahan inokulum $10 \%$. Selain itu kondisi lingkungan di dalam reaktor yaitu $\mathrm{pH}$ untuk penambahan inokulum $10 \%$ menurun tajam sehingga mendekati netral pada hari ke-40 kemudian cenderung stabil (data tidak ditampilkan).

\section{Pengaruh Jerami dalam Remediasi Logam Pb}

Pada penelitian ini dilakukan penambahan jerami sebagai bulking agents yang bertujuan untuk meningkatkan porositas tanah sehingga dapat meningkatkan aktivitas mikroba tanah. Perlakuan ini dilakukan karena hasil penelitian sebelumnya menunjukkan bahwa logam $\mathrm{Pb}$ pada fase tertukarkan dapat berpindah ke fase residual dalam waktu 42 hari dengan adanya penambahan bulking agents (Huang et al., 2005). Pengaruh jerami (kontrol jerami, inokulum $5 \%+$ jerami dibandingkan dengan kontrol negatif dan penambahan inokulum 5\%) pada tanah terkontaminasi $\mathrm{Pb}$ pada fase tertukarkan dan fase residual dapat dilihat pada Gambar 6A dan 6B.

Secara umum penambahan jerami dapat menurunkan konsentrasi $\mathrm{Pb}$ pada fase tertukarkan jika dibandingkan dengan kontrol negatif. Konsentrasi $\mathrm{Pb}$ pada penambahan inokulum $5 \%+$ jerami pada fase tertukarkan menurun sejumlah $20 \%$ selama waktu inkubasi 40 hari jika dibandingkan dengan kontrol negatif. Hal ini menunjukkan jerami dapat meningkatkan proses remediasi $\mathrm{Pb}$ karena porositas tanah 

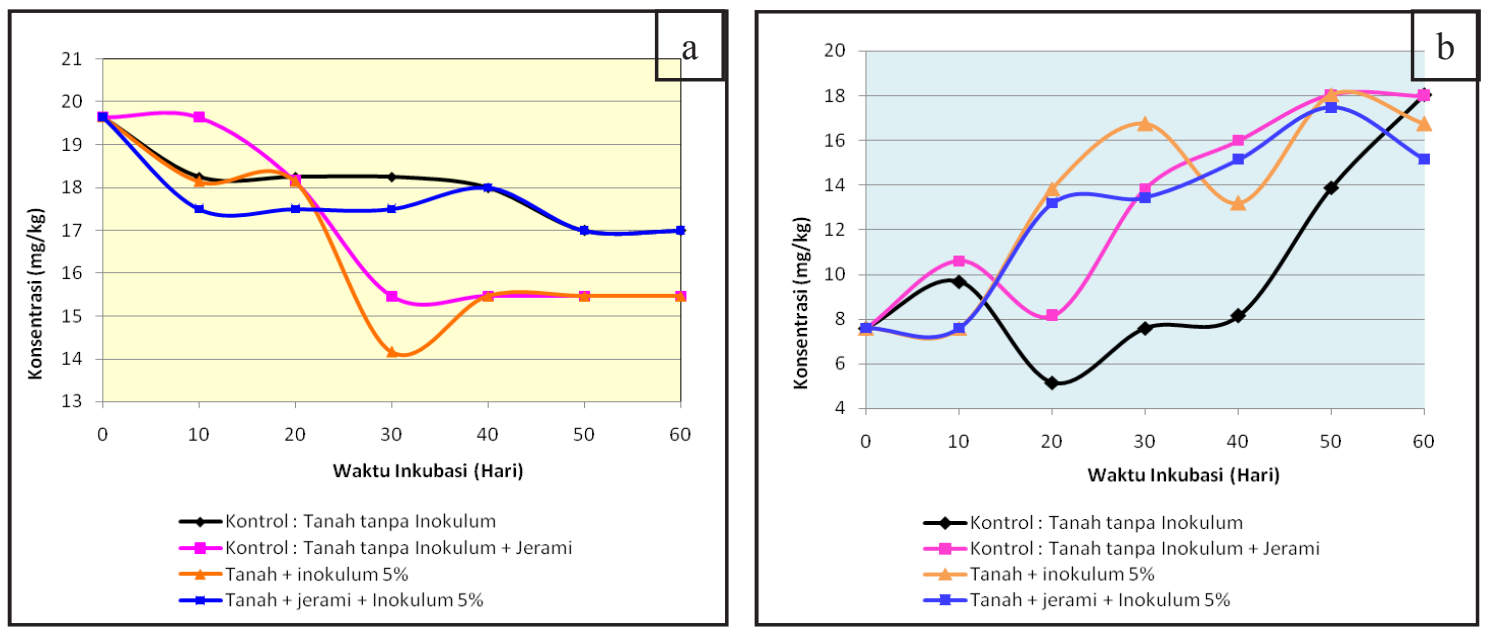

Gambar 6. Pengaruh Perlakuan Jerami pada Konsentrasi $\mathrm{Pb}$ pada Beberapa Fase
a. Fase Tertukarkan
b. Fase Residual

menjadi lebih baik sehingga aktivitas mikroba meningkat. Penambahan inokulum 5\%+jerami dapat menurunkan konsentrasi $\mathrm{Pb}$ pada fase tertukarkan sejumlah $10 \%$ jika dibandingkan dengan kontrol jerami.

Hasil pengamatan menunjukkan konsentrasi $\mathrm{Pb}$ pada fase tertukarkan menurun sebesar $16,67 \%$ jika dibandingkan dengan konsentrasi awal. Penurunan konsentrasi ini diikuti dengan meningkatnya konsentrasi logam $\mathrm{Pb}$ pada fase residual sebesar $144,14 \%$ yaitu dari $7,77 \mathrm{mg} / \mathrm{kg}$ menjadi $18,97 \mathrm{mg} / \mathrm{kg}$. Konsentrasi logam Pb pada fase residualmulai meningkat pada waktu inkubasi 20 hari kemudian meningkat tajam sebesar 125\% pada waktu inkubasi 50 hari kemudian cenderung konstan. Hal ini menunjukkan penambahan jerami dapat membantu proses remediasi $\mathrm{Pb}$ seperti terlihat pada perlakuan kontrol jerami dan inokulum $5 \%+$ jerami yang ditunjukkan dengan meningkatnya konsentrasi $\mathrm{Pb}$ pada fase residual jika dibandingkan dengan konsentrasi $\mathrm{Pb}$ pada fase tertukarkan selama waktu inkubasi.

Namun peningkatan konsentrasi logam $\mathrm{Pb}$ pada fase residual ini masih lebih rendah jika dibandingkan dengan penambahan inokulum sejumlah 5\% pada waktu inkubasi 40 hari yaitu sebesar 142\%. Berdasarkan waktu inkubasi, kondisi optimum remediasi $\mathrm{Pb}$ pada tanah terkontaminasi untuk perlakuan inokulum $5 \%+$ jerami diperoleh pada waktu inkubasi 50 hari jika dibandingkan dengan inokulum 5\% (30 hari). Hal ini menunjukkan bahwa jerami dapat meningkatkan aktivitas mikroba tanah terutama mikroba indigenous dengan cara memberikan kondisi lingkungan yang lebih sesuai untuk kehidupan mikroba tersebut. Hal ini ditunjukkan dengan meningkatnya jumlah mikroba tanah dan tingginya produksi $\mathrm{CO}_{2}$ pada perlakuan penambahan jerami jika dibandingkan dengan penambahan inokulum. Akibatnya konsorsium mikroba yang ditambahkan tidak mampu berkompetisi dengan mikroba indigenous sehingga tidak terlalu efektif dalam meremediasi $\mathrm{Pb}$. Hal ini ditunjukkan dengan lambatnya proses remediasi $\mathrm{Pb}$ pada perlakuan penambahan jerami dibandingkan dengan penambahan inokulum dengan konsentrasi inokulum yang sama. Hal ini sesuai dengan pernyataan Chatterjee, et al. (2008) yaitu efektivitas remediasi kontaminan secara alamiah tergantung pada miroba indigenous tanah namun terjadi pada kecepatan yang rendah. Hasil penelitian secara umum menunjukkan konsorsium mikroba yang digunakan lebih efektif merediasi logam $\mathrm{Pb}$ pada tanah yang terkontaminasi $\mathrm{Pb}$ jika dibandingkan dengan penambahan inokulum+jerami. Hal ini ditunjukkan dengan kecepatan remediasi yang lebih cepat pada perlakuan penambahan inokulum dibandingkan dengan penambahan jerami dan inokulum+jerami.

\section{Karakteristik Tanah Setelah Proses Remediasi}

Analisis sifat fisika-kimia tanah sebelum dan sesudah diremediasi dapat dilihat pada Tabel 2 . Analisis sifat fisika kimia tanah hanya dilakukan untuk kondisi remediasi $\mathrm{Pb}$ yang optimum yaitu penambahan inokulum $10 \%$ pada waktu inkubasi 
40 hari. Secara umum, karakteristik fisika kimia tanah setelah diremediasi lebih baik jika dibandingkan dengan sebelum diremediasi. $\mathrm{pH}$ tanah setelah diremediasi cenderung meningkat, artinya terdapat peningkatan ion $\mathrm{OH}$, yang berarti muatan partikel akan berubah menjadi lebih negatif. Hal ini ditunjukkan adanya peningkatan ion logam mineral pada tanah liat yang mengandung oksida Fe. Meningkatnya $\mathrm{pH}$ tanah tersebut menyebabkan tanah menjadi jenuh oleh alkali tanah akibatnya kejenuhan basa (KB) tanah akan meningkat. Semakin alkali tanah maka pertukaran kation oleh partikel tanah akan semakin baik.
Berdasarkan pengamatan terhadap unsur hara makro seperti fosfor, proses remediasi memberikan pengaruh positif terhadap tanah, hal ini terlihat dari peningkatan kandungan $\mathrm{P}_{2} \mathrm{O}_{5}$ yang berasal dari hasil perombakan bahan organik oleh mikroba. Hal yang serupa juga ditemui untuk kandungan hara kalium, kondisi ini memberikan keuntungan karena ketersediaan unsur $\mathrm{K}$ bagi tanaman menjadi lebih banyak. Selain itu juga diketahui adanya peningkatan ratio jumlah alkali tanah terhadap Kapasitas Tukar Kation (KTK), kondisi ini menunjukkan bahwa $\mathrm{pH}$ tanah akan mengarah ke alkali. Jika tanah menjadi alkali maka logam berat akan berada pada kondisi

Tabel 3. Hasil Analisis Fisika-Kimia Tanah Terkontaminasi Sebelum dan Setelah Remediasi

\begin{tabular}{|c|c|c|c|}
\hline No & Parameter & $\begin{array}{l}\text { Tanah terkontaminasi } \\
\text { sebelum Bioremediasi }\end{array}$ & $\begin{array}{l}\text { Tanah terkontaminas } \\
\text { setelah Bioremediasi }\end{array}$ \\
\hline \multirow{4}{*}{1} & Tekstur & & \\
\hline & Pasir, \% & 20 & 16 \\
\hline & Debu,\% & 21 & 57 \\
\hline & Liat, $\%$ & 59 & 28 \\
\hline 2 & $\mathrm{pH}$ & 7,1 & 7,6 \\
\hline \multirow{3}{*}{3} & Nitrogen $(\mathrm{N}), \%$ & 0,15 & 0,36 \\
\hline & Karbon (C),\% & 2,97 & 6,80 \\
\hline & Rasio $(\mathrm{C} / \mathrm{N}), \%$ & 19 & 19 \\
\hline 4 & $\mathrm{P}_{2} \mathrm{O}_{5} \mathrm{HCl} 25 \%, \mathrm{ppm}$ & 38,7 & 77,3 \\
\hline 5 & Kalium $(\mathrm{K}), \mathrm{mg} / \mathrm{kg}$ & 159,2 & 802,2 \\
\hline 6 & $\begin{array}{l}\text { Kapasitas Tukar Kation (KTK), } \\
\text { me/100g }\end{array}$ & 37,55 & 12,27 \\
\hline 7 & Nilai Kejenuhan Basa (KB), \% & 123 & 236 \\
\hline \multirow{3}{*}{8} & Ext $\mathrm{HCl} 25 \%$ & & \\
\hline & $\mathrm{P} 2 \mathrm{O} 5, \mathrm{ppm}$ & 600,4 & 289,5 \\
\hline & $\mathrm{K} 2 \mathrm{O}, \mathrm{ppm}$ & 487,8 & 802,8 \\
\hline \multirow{5}{*}{9} & Unsur hara & & \\
\hline & $\mathrm{Ca}, \mathrm{me} / 100 \mathrm{~g}$ & 40,33 & $\begin{array}{c}24,48 \\
1,38\end{array}$ \\
\hline & $\mathrm{Mg}, \mathrm{me} / 100 \mathrm{~g}$ & 5,37 & 1,58 \\
\hline & $\mathrm{K}, \mathrm{me} / 100 \mathrm{~g}$ & 0,44 & 2,91 \\
\hline & $\mathrm{Na}, \mathrm{me} / 100 \mathrm{~g}$ & 0,21 & \\
\hline \multirow{7}{*}{10} & Hara lain & & \\
\hline & $\mathrm{Fe}, \mathrm{me} / 100 \mathrm{~g}$ & 2,9 & 6,7 \\
\hline & $\mathrm{Mn}, \mathrm{me} / 100 \mathrm{~g}$ & 36,8 & 41,1 \\
\hline & $\mathrm{Cu}, \mathrm{me} / 100 \mathrm{~g}$ & 0,6 & 1,1 \\
\hline & $\mathrm{Zn}, \mathrm{me} / 100 \mathrm{~g}$ & 4,8 & 10,3 \\
\hline & $\mathrm{S}, \mathrm{me} / 100 \mathrm{~g}$ & 13,4 & 34,2 \\
\hline & $\mathrm{Al}, \mathrm{me} / 100 \mathrm{~g}$ & 42,1 & 34,0 \\
\hline
\end{tabular}

Sumber data : Laboratorium Penguji, Badan Penelitian dan Pengembangan Pertanian, Hortikultura, Lembang, 2010 
stabil dan tidak mudah untuk dipertukarkan. Hal ini ditunjukkan dengan menurunkan KTK tanah terkontaminasi setelah diremediasi dibandingkan dengan kondisi awal. Hasil analisis menunjukkan nilai Kejenuhan Basa (KB) pada tanah yang telah diremediasi meningkat sejumlah dua kali jika dibandingkan dengan tanah sebelum diremediasi artinya jumlah alkali bebas meningkat akibatnya pH tanah menjadi alkali. Jika dihubungkan dengan keberadaan logam berat di tanah, tanah akan memiliki kemampuan serap logam yang lebih tinggi. Kondisi ini sejalan dengan keberadaan logam setelah remediasi, yaitu menurunnya konsentrasi logam $\mathrm{Pb}$ pada fase tertukarkan (aktif) jika dibandingkan dengan meningkatnya konsentrasi logam $\mathrm{Pb}$ dalam fase residual (inaktif). Hal ini menunjukkan bahwa logam $\mathrm{Pb}$ bersifat lebih stabil sehingga semakin sulit di-absorb oleh tanaman (Miretzky dan Cirelli, 2008), akibatnya toksisitas tanah untuk tanaman menjadi berkurang. Meningkatnya unsur alkali tanah ini secara tidak langsung akan meningkatkan kandungan unsur hara mikro tanah, yang ditunjukkan dengan meningkatnya unsur $\mathrm{Fe}, \mathrm{Mn}, \mathrm{Cu}, \mathrm{Zn}$ dan $\mathrm{S}$ sejumlah 1- 3 kali lipat jika dibandingkan dengan tanah terkontaminasi sebelum diremediasi.

\section{KESIMPULAN}

Konsorsium mikroba yang terdiri dari empat jenis mikroba pengakumulasi $\mathrm{Pb}$ diketahui mampu meremediasi tanah terkontaminasi $\mathrm{Pb}$ dari sludge industri kertas proses deinking dengan kecepatan yang lebih tinggi dibandingkan penambahan konsorsium mikroba 5\% dengan jerami padi sebagai bulking agents. Hal ini ditandai dengan menurunnya konsentrasi logam $\mathrm{Pb}$ pada fase tertukarkan (aktif) menjadi fase residual (in aktif). Perubahan fase tersebut optimal terjadi pada waktu inkubasi 40 hari untuk penambahan inokulum mikroba $10 \%(\mathrm{v} / \mathrm{w})$, dan waktu inkubasi 50 hari pada penambahan mikroba 5\%+jerami. Penambahan jerami dapat meningkatkan aktivitas mikroba indigenous tanah yang ditunjukkan dengan meningkatnya jumlah mikroba tanah dan produksi $\mathrm{CO}_{2}$ yang dihasilkan dibandingkan penambahan inokulum mikroba dan kontrol negatif karena dapat memberikan kondisi lingkungan yang lebih sesuai untuk kehidupan mikroba tanah. Karakteristik tanah terkontaminasi yang telah diremediasi oleh konsorsium mikroba menjadi lebih baik karena kandungan unsur hara tanah baik makro maupun mikro meningkat dibandingkan sebelum diremediasi.

\section{Ucapan Terima Kasih}

Kami menyampaikan terima kasih yang sebesar-besarnya kepada Kementerian Negara Riset dan Teknologi yang telah menyediakan dana insentif, PT. Adiprima Suraprinta yang telah menyediakan tanah terkontaminasi $\mathrm{Pb}$ serta bantuan dan kerjasama yang baik dari teknisi litkayasa BBPK sehingga penelitian ini dapat dilaksanakan dengan baik.

\section{DAFTAR PUSTAKA}

Alloway, B.J. 1995. Heavy Metals in Soils. $2^{\text {nd }}$ ed. Blackie Academic and Professional, Chapman \& Hall.

Amanda, J.Z. and C.W. David. 2010. Heavy Metal and Trace Metal Analysis in Soil by Sequential Extraction: A Review of Procedures. International Journal of Analytical Chemistry, Volume 2010, Article ID 387803, Hindawi Publishing Corportion

Chatterjee, S., Pritam Chattopadhyay, Subhasita Roy, and Sukanta K. Sen. 2008. Bioremediation: A Tool for Cleaning Polluted Environments. Journal of Applied Biosciences, 11: 594 - 601.

Erny, Y., N.S Dwi, S. Rasti. 2003. Koleksi, Karakterisasi dan Preservasi Mikroba Remediasi. Prosiding Seminar Hasil Penelitian Rintisan dan Bioteknologi Tanaman.

Gadd, G.M.2010. Metals, Minerals and Microbes: Geomicrobiology and Bioremediation. Microbiology, 156: 609-643.

Gottsching, L and Pakarinen, H. 2000. Recycled Fiber and Deinking. Papermaking Science and Technology, TAPPI

Hardiani, H. 2008. Pemulihan Lahan Terkontaminasi Limbah B3 dari Proses Deinking Industri Kertas Secara Fitoremediasi. Jurnal Riset Industri. Vol. 2, No. 2. ISSN. 1978-5852, Hal. 64-75.

Hardiani, H., Teddy Kardiansyah dan Susi Sugesty. 2011. Bioremediasi Logam Timbal $(\mathrm{Pb})$ Dalam Tanah Terkontaminasi Limbah Sludge Industri Kertas Proses Deinking. Jurnal Selulosa. Vol. 1, no. 1. Hal. 31-41. ISSN 2088-7000. No. 754/D.2/2010. 
Huang, D.L., Guang-Ming Zenga, Xiao-Yun Jiang, Chong-Ling Feng, Hong-Yan Yu, Guo-He Huanga, Hong-Liang Liu. 2005. Bioremediation of $\mathrm{Pb}$ Contaminated Soil by Incubating with Phanerochaete chrysosporium and Straw. College of Environmental Science and Engineering, Hunan University, Changsha 410082, Hunan, China.

Mamik, S. 2004. Pemanfaatan Bakteri Pengakumulasi Logam Berat Pb dan $\mathrm{Cd}$ untuk Menurunkan Kandungan Logam Berat Pada Beras Tercemar Limbah Industri. Tesis, Sekolah Pascasarjana, Institut Pertanian Bogor.

Margareth, C dan Sarwoko Mangkoedihardjo. 2010. Compost as Biocarrier for Remediation of Lead Polluted Soil. International Journal of Academic Research, 2 (5).

Miretzky, P and Alicia Fernandez-Cirelli. 2008. Phosphates for Pb Immobilization in Soils: A review. Environ Chem Lett, 6 (3): 121 - 133.
Notodarmojo, S. 2005. Pencemaran Tanah dan Air Tanah. Penerbit ITB. ISBN 979-350743-8

Shah, K. and J.M. Nongkynrih. 2007. Metal Hyperaccumulation and Bioremediation. Biologia Plantarum, 51 (4): 618-634.

Suhendrayatna. 2001. Bioremoval Logam Berat dengan Menggunakan Mikroorganisme: Suatu Kajian Kepustakaan (Heavy Metal Bioremoval by Microorganisms: A Literature Study) Sinergy Forum - PPI Tokyo Institute of Technology

Wasay, S.A., W. J. Parker, and P. J. VanGeel. 2002. Removal of Lead from a Calcareous Soil by Chloride Complexation. Soil and Sediment Contamination, 11(6):841-859.

Yoon, J. 2005. Phosphate-Induced Lead Immobilization in Contaminated Soil. A Thesis Presented to The Graduate School of The University of Florida. 